\title{
Radiological signs of pneumoperitoneum in an extremely low birthweight infant
}

\author{
Shilpee Raturi, ${ }^{1}$ Suresh Chandran, ${ }^{1}$ Teo Eu-leong Harvey James, ${ }^{2}$ \\ Victor Samuel Rajadurai ${ }^{1}$
}

${ }^{1}$ Department of Neonatology, KK Women's and Children's Hospital, Singapore

${ }^{2}$ Department of Diagnostic and Interventional Imaging, KK Women's and Children's Hospital, Singapore

\section{Correspondence to}

Dr Suresh Chandran, schandran1312@yahoo.co.uk

Accepted 18 August 2014
CrossMark

To cite: Raturi $S$, Chandran S, James TE-leong $\mathrm{H}$, et al. BMJ Case Rep Published online: [please include Day Month Year] doi:10.1136/bcr-2014205510

\section{DESCRIPTION}

A twin male infant weighing $820 \mathrm{~g}$ was born at $26^{+5}$ weeks of gestation. At birth he received mechanical ventilation, surfactant and subsequently indomethacin treatment for a large patent ductus arteriosus.

On day 8 of life he had frequent episodes of desaturations. Transillumination of the chest was negative. Abdominal examination and laboratory studies were unremarkable. Chest and abdominal radiographs showed signs of pneumoperitoneum. These included presence of subdiaphragmatic air in the right upper quadrant, Rigler's sign, falciform ligament sign, cupola sign and scrotal air (figures 1 and 2). An emergency laparotomy revealed an isolated perforation of jejunum, which was repaired.

Rigler's sign-Double wall or bas-relief sign, first described by Leo Rigler, ${ }^{1}$ where both outer and inner walls of the bowel wall can be visualised when there is air in the peritoneal cavity and within the intestinal lumen.

A variant of Rigler's sign occurs where the outside of the bowel wall is visible because the lumen is filled with fluid. A pseudo-double wall sign is produced when two loops of distended bowel are

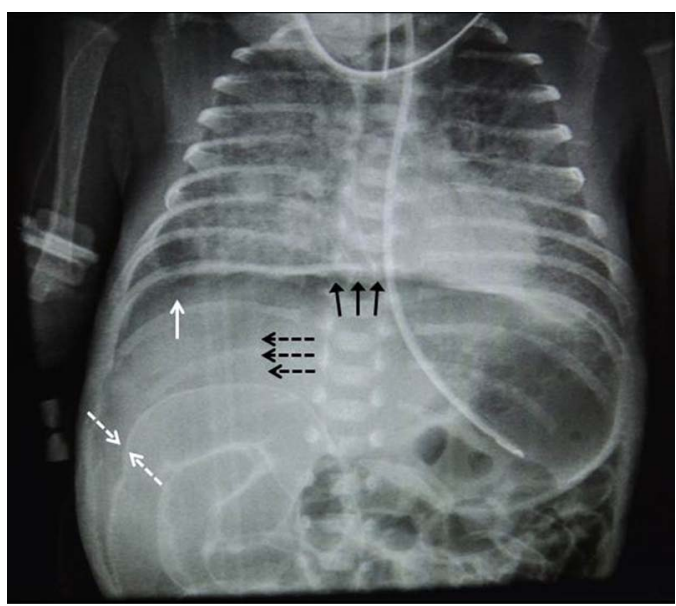

Figure 1 Supine radiograph of the chest including the upper part of the abdomen showing the presence of free intraperitoneal gas as evidenced by the outlining of the falciform ligament (dashed black arrows), the presence of air on both sides of the bowel wall (dashed white arrows), known as Rigler's sign, subdiaphragmatic air in the right upper quadrant (solid white arrow) and cupola sign showing air within the median subphrenic space (solid black arrows).

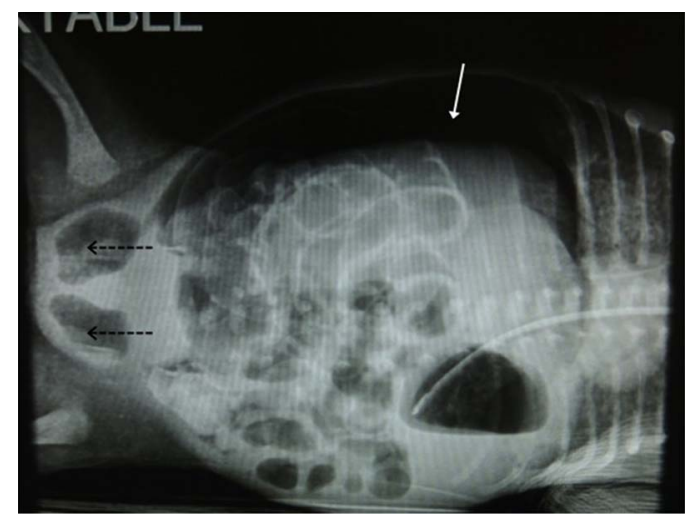

Figure 2 Left decubitus abdominal radiograph showing the presence of free intraperitoneal air outlining the right lateral abdominal wall (solid white arrow). Rigler's sign (dashed white arrows) and air in the scrotum (dashed black arrows).

adjacent to each other and their adjoining wall are outlined by intraluminal gas in both loops. ${ }^{2}$

Falciform ligament sign (Silver sign)-Falciform ligament appears as a linear density running parallel to the right border of the spine when free air lies on either side of it. ${ }^{3}$

Cupola sign (Lord Nelson's hat sign)—Inverted cup-shaped arcuate lucency seen in supine radiographs within the median subphrenic space. ${ }^{4}$

\section{Learning points}

- Radiological imaging is a vital tool and subtle imaging signs that can alert a physician towards the presence of a pneumoperitoneum must be specifically looked for in radiographs.

- In neonates, besides a supine film, a lateral decubitus view should be taken to confirm suspected-free air, when in doubt.

- Early recognition of these useful radiological signs of pneumoperitoneum followed by immediate intervention can be life saving.

Contributors SR wrote the case under the supervision of SC who summarised the findings and did appropriate literature search. TE-IH reported the findings. VSR edited the report and approved.

Competing interests None.

Patient consent Obtained. 
Provenance and peer review Not commissioned; externally peer reviewed.

\section{REFERENCES}

1 Rigler LG. Spontaneous peumoperitoneum: a roentgenologic sign found in the supine position. Radiology 1941;37:604-7.
2 de Lacey G, Bloomberg T, Wignall OK. Pneumoperitoneum: the misleading double wall sign. Clin Radiol 1977;28:445-8.

3 Hokama A, Nakamura M, Kinjo F, et al. The falciform ligament sign of pneumoperitoneum. J Emerg Trauma Shock 2011;4:440.

4 Mindelzun RE, McCort JJ. The cupola sign of pneumoperitoneum in the supine patient. Gastrointest Radiol 1986;11:283-5.

Copyright 2014 BMJ Publishing Group. All rights reserved. For permission to reuse any of this content visit http://group.bmj.com/group/rights-licensing/permissions.

BMJ Case Report Fellows may re-use this article for personal use and teaching without any further permission.

Become a Fellow of BMJ Case Reports today and you can:

- Submit as many cases as you like

- Enjoy fast sympathetic peer review and rapid publication of accepted articles

- Access all the published articles

- Re-use any of the published material for personal use and teaching without further permission

For information on Institutional Fellowships contact consortiasales@bmjgroup.com

Visit casereports.bmj.com for more articles like this and to become a Fellow 